J. Perinat. Med. 15 (1987) 340

\section{Fetal catecholamines and the Apgar score}

\author{
Lars Nylund ${ }^{1}$, Ingrid Dahlin ${ }^{2}$, and Hugo Lagercrantz ${ }^{3}$
}

${ }^{1}$ Department of Obstetrics and Gynecology, Huddinge University Hospital, Karolinska Institute, ${ }^{2}$ Department of Physiology, Karolinska Institute, and ${ }^{3}$ Department of Pediatrics, Karolinska Hospital, Karolinska Institute, Stockholm, Sweden

\section{Introduction}

The Apgar score is ubiquitously used as an index of fetal asphyxia. Recently its reliability as a quantitative index of asphyxia has been questioned. SYKES et al. [13] reported that only $21 \%$ of babies with a $1 \mathrm{~min}$. Apgar score less than 7 had severe acidosis defined as an umbilical artery $\mathrm{pH}$ less or equal to 7.10 . On the other hand $73 \%$ of the babies with a severe acidosis had an Apgar score greater than 7 at $1 \mathrm{~min}$. The rise of the catecholamines in the asphyxiated fetus has been suggested as an explanation to this $[7,8,9,10,11]$. The catecholamines increase every component of the Apgar score except skin color. The heart rate is augmented, respiration is stimulated as well as reflex irritability and muscle tone [4]. In order to further elucidate the association between fetal catecholamines, fetal $\mathrm{pH}$ and Apgar score the present investigation was initiated.

\section{Material and methods}

One hundred and eighty-one singleton deliveries at Huddinge University Hospital and Karolinska Hospital were included in the investigation. Clinical data are given in table I. Arterial umbilical blood samples were obtained immediately after birth with the double clamp technique. The blood was collected in prechilled tubes containing EGTA-reduced glutathione and centrifuged in a refrigerator. The supernatant was frozen at $-60^{\circ} \mathrm{C}$ until catecholamine analysis by high performance cation exchange liquid chromatography with electrochemical detection [3]. The lowest values which could be detected was $0.1 \mathrm{nmol} / 1$ in

\section{Curriculum vitae}

LARS NYLUND was born 1949 in Sundsvall, Sweden. He studied medicine in Stockholm at Karolinska Institutet from which he was graduated in 1974. In 1982 he presented a thesis entitled "Uteroplacental blood flow - Studies with functional placental scintigraphy". At present, he is an associate professor at the Department of Obstetrics and Gynecology, Huddinge University Hospital, Huddinge. His main perinatological interests include uteroplacental blood flow and fetal sympatho-adrenal activity at birth.

$1 \mathrm{ml}$ plasma. In 16 cases adrenaline could not be analyzed because of inadequate sample volume. In these cases noradrenaline only was analyzed. $\mathrm{pH}$ was measured immediately with a Radiometer blood gas analyzer or the Corometrics $220 \mathrm{pH}$ System. Apgar score was recorded by the midwife as a clinical routine one and five minutes after delivery.

\section{Results}

The infants were divided in two groups: 167 infants with Apgar scores above 6 and 14 with Apgar scores less than 7 at 1 minute. Parity and birth weights were similar in the two groups but the gestational age was higher in the infants with normal Apgar scores (table I). The median umbili- 
Table I. Clinical data. Comparison between infants with Apgar score $<7$ and those with Apgar score $>6$; 1 minute after birth.

\begin{tabular}{llll}
\hline & Apgar score $<7$ & Apgar score $>6$ & $\mathrm{p}$ \\
\hline $\mathrm{n}$ & 14 & 167 & - \\
Parity & $1(0-2)$ & $1(0-3)$ & $\mathrm{n} . \mathrm{s}$. \\
Gestation (weeks) & $37.5(29-42)$ & $39(33-43)$ & $<0.01$ \\
Fetal weight (g) & $3315(1130-4455)$ & $3420(2210-4810)$ & $\mathrm{n}$. s. \\
Apgar score at 1 min. & $5(2-6)$ & $9(7-10)$ & - \\
Apgar score at 5 min. & $8(7-10)$ & $10(7-10)$ & $<0.0001$ \\
Apgar score at 10 min. & $9(8-10)$ & $10(8-10)$ & $<0.0001$ \\
Preeclamptic patients (n) & 2 & 10 & \\
Diabetic patients (n) & 2 & 11 & \\
Cesarean sections (n) & 4 & 31 & \\
Vacuum extractions (n) & 3 & 22 & \\
Low forceps (n) & 0 & 1 & \\
Paracervical block (n) & 0 & 4 & \\
\hline
\end{tabular}

Mann-Whitney test. Values given as median (range).

cal arterial $\mathrm{pH}$ was 7.26 in the normal Apgar group and 7.21 in the group with depressed Apgar score $(\mathrm{p}<0.05$, table II). Median noradrenaline levels were significantly higher in the infants with Apgar score less than 7. No statistically significant difference was found between the adrenaline levels (table II). When Apgar score was above 6 at $1 \mathrm{~min} .73$ of the 167 infants $(44 \%)$ were acidotic defined as an umbilical artery $\mathrm{pH}$ below 7.25. We found that there was a significant negative correlation between ${ }^{10} \log$ noradrenaline and umbilical artery $\mathrm{pH}$ (coefficient of correlation $=0.52, \mathrm{p}<0.001)$ and between ${ }^{10} \log$ adrenaline and $\mathrm{pH}$ (coefficient of correlation $=0.40$, $\mathrm{p}<0.001$; figures 1 and 2).

The 14 infants with Apgar score below 7 also showed a significant negative correlation between ${ }^{10} \log$ noradrenaline and $\mathrm{pH}(\mathrm{r}=0.60, \mathrm{p}<0.05)$ and between ${ }^{10} \log$ adrenaline and $\mathrm{pH}(\mathrm{r}=0.77$, $\mathrm{p}<0.01$; figure 3 ).

No correlation between catecholamines and fetal weight or between catecholamines and gestational age was found neither in the infants with Apgar score depressed below 7 nor in the group with Apgar score at or above 7.

We found no statistically significant differences between the sexes when the catecholamine levels were compared.

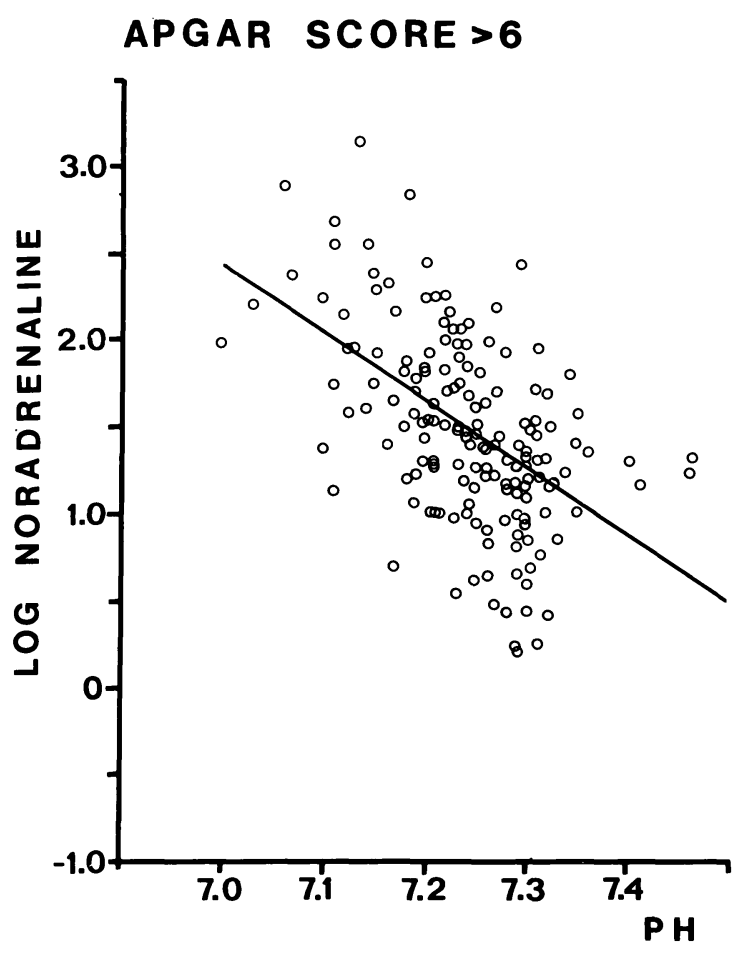

Figure 1. Linear correlation between umbilical arterial $\log$ noradrenaline (nmol/1) and $\mathrm{pH}$ in the group of infants with Apgar score above or equal to seven. $\mathrm{n}=167, \mathrm{r}=0.52, \mathrm{p}<0.001$. 
Table II. Umbilical arterial $\mathrm{pH}$ and catecholamine values. Comparison between infants with Apgar score $<7$ and those with Apgar score $>6 ; 1$ minute after birth.

\begin{tabular}{llll}
\hline & Apgar score $<7$ & Apgar score $>6$ & $\mathrm{p}$ \\
\hline $\mathrm{n}$ & 14 & 167 & \\
Umbilical arterial pH & $7.21(7.02-7.32)$ & $7.26(7.02-7.47)$ & $<0.05$ \\
Noradrenaline $(\mathrm{nmol} / \mathrm{l})$ & $119(8.7-560)$ & $28.3(1.7-1440)$ & $<0.01$ \\
Adrenaline $(\mathrm{nmol} / \mathrm{l})$ & $5.2(0.7-32.8)$ & $4.1(0-104)$ & n. s. \\
\hline
\end{tabular}

Mann-Whitney test. Values given as median (range).

Adrenaline could not be analyzed in 16 of the infants with high Apgar score due to insufficient sample volume.

APGAR SCORE > 6

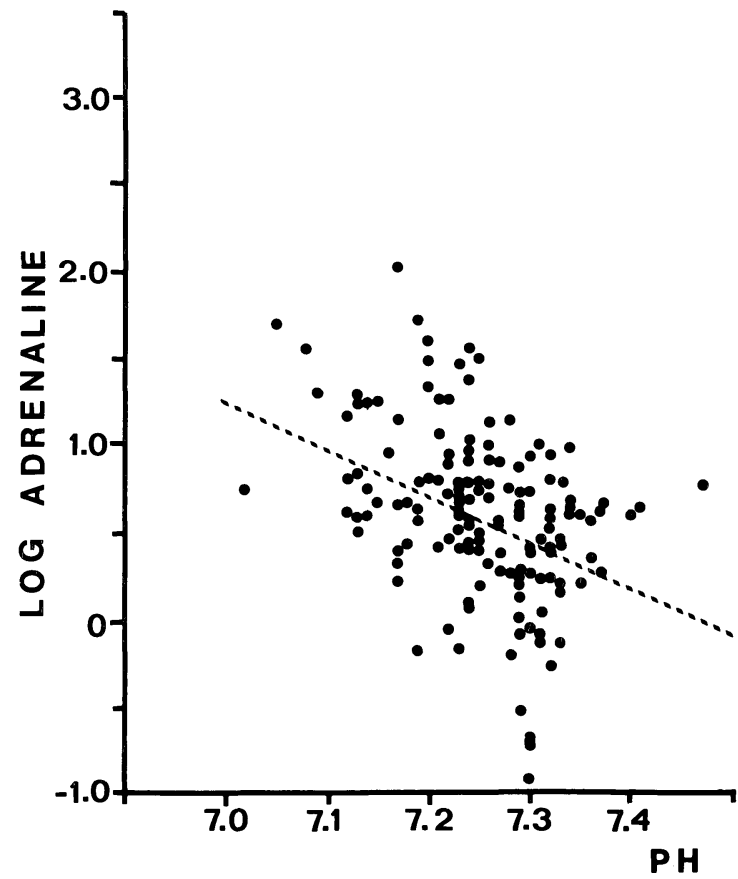

Figure 2. Linear correlation between umbilical arterial $\log$ adrenaline $(\mathrm{nmol} / \mathrm{l})$ and $\mathrm{pH}$ in the group of infants with Apgar score above or equal to seven. $\mathrm{n}=151$, $\mathrm{r}=0.40, \mathrm{p}<0.001$. Adrenaline was not analyzed in 16 of the 167 infants with Apgar $>6$ due to inadequate sample volume.

\section{Discussion}

The material represents a fairly typical mixture of uneventful and complicated deliveries in university hospitals. Even though complicated deliveries are overrepresented to some extent, we were surprised to find that about half of the infants
APGAR SCORE $<7$

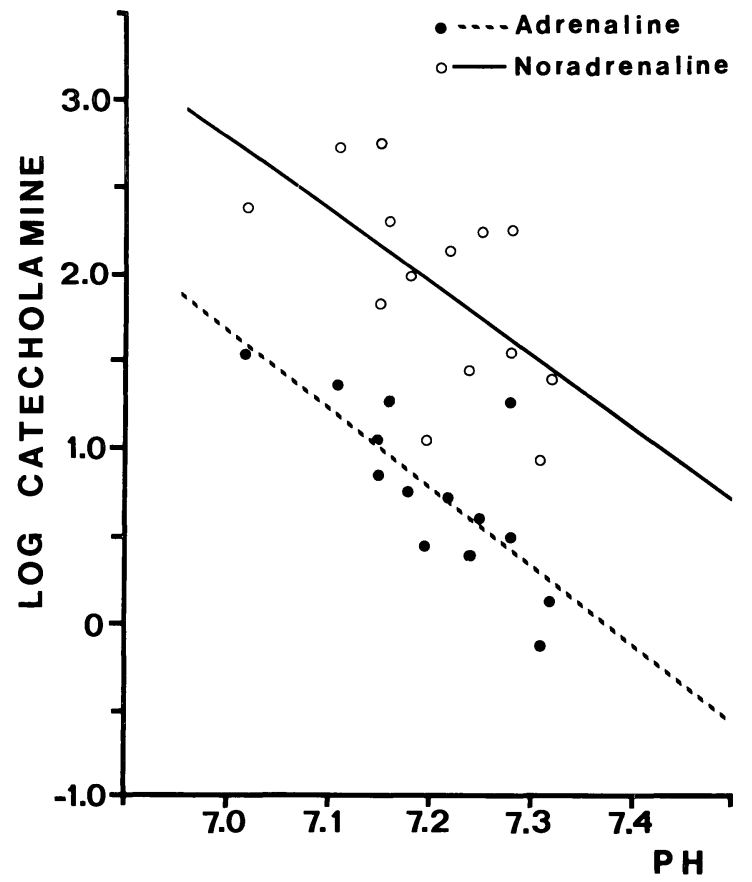

Figure 3. Linear correlation between umbilical arterial $\log$ catecholamine $(\mathrm{nmol} / \mathrm{l})$ and $\mathrm{pH}$ in the group of infants with Apgar score less than seven. Noradrenaline: $\mathrm{n}=14, \quad \mathrm{r}=0.60, \quad \mathrm{p}<0.05$. Adrenaline: $\mathrm{n}=14$, $\mathrm{r}=0.77, \mathrm{p}<0.01$.

had umbilical $\mathrm{pH}$ below 7.25 and were thus asphyxiated according to the definition by SALING [12]. However, only 8 per cent of the cases had Apgar score below 7 at one minute, the conventional definition of asphyxia. This discrepancy between Apgar score and $\mathrm{pH}$ agrees well with the 
findings by SyKes et al. [13]. Our hypothesis was that the high concentrations of catecholamines at birth can overcome the effects of asphyxia.

The correlation between $\mathrm{pH}$ and catecholamines was found to be highly significant in agreement with previous findings $[6,11,14]$. This occurred regardless of the Apgar score. It is well known that asphyxia can stimulate release of catecholamines probably mainly from the medulla of the adrenal glands and the paraganglia [5].

Most of the infants with low $\mathrm{pH}$ had normal Apgar score, even four infants with $\mathrm{pH}$ below 7.10. We believe that this is explained by their high catecholamine levels. The values seen in these infants were enormously high if compared to those during stress conditions later in life. This high sympathoadrenal activity can probably sustain the homeostasis and overcome the detrimental effects of asphyxia. The catecholamines do indeed increase cardiac performance [1], stimulate breathing, increase irritability and tone. Only the score for skin color is lowered by the catecholamines.

In fourteen infants Apgar score was below 7 in spite of that their catecholamine levels were similar in relation to $\mathrm{pH}$. One possible explanation to this finding is that these infants had lower gestational age and did not respond to the catecholamine surge to the same extent as the other infants in agreement with a study particularly on catecholamine levels in preterm infants [2].

The present results confirm previous reports showing that high Apgar scores often can be associated with low $\mathrm{pH}$ values. On the other hand the correlations between low $\mathrm{pH}$ and high catecholamine levels suggest that the catecholamine surge improves the Apgar score in acidotic infants.

\section{Summary}

The association between Apgar score, $\mathrm{pH}$ and catecholamine levels was investigated in 181 newborn infants with a gestational age between 29 and 43 completed weeks. Umbilical arterial blood was obtained before the first breath with the double clamp technique and $\mathrm{pH}$ was measured. Plasma adrenaline and noradrenaline were analyzed by high performance liquid chromatography. The Apgar score at 1 minute was above or equal to seven in 167 infants. Forty-four per cent of these infants had $\mathrm{pH}$ below 7.25. A negative correlation between $\log$ noradrenaline and $\mathrm{pH}(\mathrm{r}=0.52, \mathrm{p}<0.001)$ and

between $\log$ adrenaline and $\mathrm{pH}(\mathrm{r}=0.40, \mathrm{p}<0.001)$ was found.

In 14 infants the Apgar score was below seven. The median $\mathrm{pH}$ was 7.21 (range 7.02-7.32). Also in this group a negative correlation between log noradrenaline and $\mathrm{pH}(\mathrm{r}=0.60, \mathrm{p}<0.05)$ and between log adrenaline and $\mathrm{pH}(\mathrm{r}=0.77, \mathrm{p}<0.01)$ was noted. We concluded that the Apgar score is an insufficient measure of fetal asphyxia defined as fetal acidosis but rather reflects the vitality of the newborn.

Keywords: Adrenaline, Apgar score, asphyxia, catecholamines, noradrenaline, $\mathrm{pH}$ umbilical artery, sympathoadrenal activity.

\section{Zusammenfassung}

\section{Fetale Katecholamine und das Apgar-Schema}

Der Zusammenhang zwischen Apgar-Schema, pH-Werten und Katecholaminspiegel wurde an 181 Neugeborenen mit einem Gestationsalter zwischen 29 und 43 vollendeter Woche bestimmt. Arterielles Nabelschnurblut wurde vor dem ersten Atemzug mit der Doppelklammertechnik gewonnen und der $\mathrm{pH}$-Wert bestimmt. Plasmaadrenalin- und Noradrenalinspiegel wurden mit der Hochleistungsflüssigchromatographie analysiert. Das Apgar-Schema war nach einer Minute größer oder gleich sieben bei 167 der Neugeborenen. 44\% dieser Kinder hatten einen $\mathrm{pH}$-Wert unter 7,25. Eine negative Korrelation bestand zwischen dem Logarithmus von Noradre- nalin und dem $\mathrm{pH}(\mathrm{r}=0,52, \mathrm{p}<0,001)$ und zwischen dem Logarithmus von Adrenalin und dem $\mathrm{pH}(\mathrm{r}=0,40$, $\mathrm{p}<0,001)$.

Bei 14 Neugeborenen war das Apgar-Schema unter 7. Der mittlere pH-Wert betrug 7,21 (zwischen 7,02 und 7,32). In dieser Gruppe bestand ebenfalls eine negative Korrelation zwischen dem Logarithmus von Noradrenalin und dem $\mathrm{pH}(\mathrm{r}=0,60, \mathrm{p}<0,05)$ und zwischen dem Logarithmus von Adrenalin und dem $\mathrm{pH}(\mathrm{r}=0,77$, $\mathrm{p}<0,01)$. Wir fanden, daß das Apgar-Schema einen unzureichenden Maßstab für fetale Asphyxie, definiert als fetale Azidose, darstellt, eher spiegelt es die Vitalität des Neugeborenen wider.

Schlüsselwörter: Adrenalin, Apgar-Schema, Asphyxie, Katecholamine, Noradrenalin, Nabelschnurarterien-pH, sympathoadrenale Aktivität. 


\section{Résumé}

\section{Catécholamines fetales et score d'Apgar}

On a étudié la relation entre le score d'Apgar, le pH et le taux de catécholamines chez 181 nouveaux-nés d'âge gestationnel compris entre 29 et 43 semaines révolues. On a prélevé du sang artériel ombilical avant la première respiration par la technique du double clampage et on a mesuré le $\mathrm{pH}$. L'adrénaline et la noradrénaline plasmatiques ont été déterminés par chromatographie en phase liquide à haute performance. Le score d'Apgar a $1 \mathrm{mi}-$ nute était supérieur ou égal à 7 chez 167 enfants. $44 \%$ de ces enfants avaient un $\mathrm{pH}$ inférieur à 7,25. On a trouvé une corrélation négative entre le log de noradré- naline et le $\mathrm{pH}(\mathrm{r}=0,52 ; \mathrm{p}<0,001)$ et entre le log d'adrénaline et le $\mathrm{pH}(\mathrm{r}=0,40 ; \mathrm{p}<0,001)$.

Le score d'Apgar était inférieur à 7 chez 14 enfants. Le $\mathrm{pH}$ moyen était de 7,21 (intervalle $=7,02$ à 7,32). On a également noté dans ce groupe une corrélation négative entre le $\log$ de noradrénaline et le $\mathrm{pH}(\mathrm{r}=0,60$; $\mathrm{p}<0,05)$ et entre le log d'adrénaline et le $\mathrm{pH}(\mathrm{r}=0,77$; $p<0,01)$. Nous en concluons que le score d'Apgar est insuffisant pour mesurer l'asphyxie fœtale définie en tant qu'acidose fœtale mais qu'il reflète plutôt la vitalité du nouveau-né.

Mots-clés: Activité médullo-surrénalienne, adrénaline, asphyxie, catécholamines, noradrénaline, $\mathrm{pH}$ dans l'artère ombilicale, score d'Apgar.

\section{References}

[1] Downing SE, TH Gardner, JM Rocamora: Adrenergic support of the cardiac function during hypoxia in the newborn lamb. Am J of Physiol 217 (1969) 728

[2] Greenough A, H Lagercrantz, J Pool: Catecholamine levels in preterm infants. Acta Paediatr Scand (in press)

[3] HJemdahl P, M Daleskog, T Kahan: Determination of plasma catecholamines by high performance liquid chromatography with electrochemical detection: Comparison with a radioenzymatic method. Life Sci 25 (1979) 131

[4] Irestedt L, H Lagercrantz, P Belfrage: Causes and consequences of maternal and fetal sympathoadrenal activation during parturition. Acta Obstet Gynecol Scand [Suppl] 118 (1984) 111

[5] JONES CT: Circulating catecholamines in the fetus, their origin, actions and significance. In: PARVEZ H, S PARVEZ (eds): Biogenic amines in development. Elsevier, Amsterdam 1981

[6] Lagercrantz H, P Bistolettr: Catecholamine release in the newborn infant at birth. Pediatr Res 11 (1977) 889

[7] Lagercrantz H, P Bistoletti, L Nylund: Sympatho-adrenal activity in the fetus during delivery and at birth. In: STERN L, B SALle, B FriIS-HANSEN (eds): Intensive Care in the Newborn III. Masson \& Cie, New York 1981

[8] Lagercrantz H: Asphyxia and the Apgar score. Lancet i (1982) 966
[9] LAGERCRANTZ H: Catecholamine Surge at Birth in the Human Infant. In: Alan R (ed): Catecholamines: Basic and Peripheral Mechanisms. Liss, Inc., New York 1984

[10] Nylund L, H Lagercrantz, NO Lunell: Catecholamines in fetal blood during birth in man. J Dev Physiol 1 (1979) 427

[11] Padbury JF, B Roberman, TH Oddie, CJ Hobel, DA FISHER: Fetal catecholamine release in response to labor and delivery. Obstet Gynecol 60 (1982) 607

[12] SALING E: Amnioscopy and fetal blood sampling: Observations on foetal acidosis. Arch Dis Child 41 (1966) 472

[13] Sykes GS, P Johnson, F Ashworth, PM Molloy, W Gu, GM STIRRAT: Do Apgar scores indicate asphyxia? Lancet i (1982) 494

[14] Paulick R, E KastendieCK, H Wernze: Catecholamines in arterial and venous umbilical blood: placental extraction, correlation with fetal hypoxia, and transcutaneous partial oxygen tension. J Perinat Med 13 (1985) 31

Received April 24, 1986. Revised January 15, 1987. Accepted February 4, 1987.

Lars Nylund, M. D.

Department of Obstetrics and Gynecology

Huddinge University Hospital

S-141 86 Huddinge

Sweden 